\title{
Hostilidades e conflitos na Líbia: o difícil caminho para a democracia*
}

\section{Hostilities and Conflict in Libya: a hard road to democracy}

Erinaldo Ferreira do Carmo ${ }^{1}$ Younus Khalifa Haddod ${ }^{2}$
* Recebido em 17.08.2014 Aprovado em 13.10.2014

1 Doutor em Ciência Política pela Universidade Federal de Pernambuco; Professor de Sociologia e Política no Colégio de Aplicação do Centro de Educação da UFPE. E-mail: erinaldocarmo@gmail.com.

2 Doutorando do Centro de Estudos Sociais da Universidade de Coimbra, Portugal; Professor da Universidade de Aljabal Algharbi - Gharian, Líbia.E-mail: yuhaddood@gmail.com.

\section{Resumo}

Este artigo representa uma tentativa de compreensão do impacto das mudanças ocorridas, e ainda em curso, na Líbia após as manifestações da Primavera Árabe que resultaram na queda do regime autoritário e na implantação de mecanismos democráticos de governo, considerando as questões internas e externas e a crescente interdependência dos diferentes fatores político-econômicos sobre a sociedade líbia em sua transformação. Depois de uma série de ações desastrosas do governo de Khadafi, no âmbito local e internacional, os protestos levaram a sociedade a uma intervenção bélica direta sobre o governo e sobre o Estado. O impacto das intervenções estadunidenses nesta mudança é proeminente, devido às características peculiares ligadas à posição desta potência de um lado, e sua relação tensa com a Líbia de outro. Este trabalho apresenta alguns aspectos da problemática decorrente da contradição ideológica entre Secularismo e Islamismo Político no que diz respeito à participação no novo Estado e aos princípios da governança. Esta temática adquiriu uma importância acentuada nos atuais debates intelectuais e políticos no Mundo Árabe, e agora, mais do que nunca, uma solução democrática representa o pressuposto conciliatório entre as duas correntes antagônicas, cujo confronto já se descolou do estágio do discurso teórico para a luta armada.

Palavras-chave: Líbia. Secularismo. Islamismo politico. Mundo Árabe, Democracia.

\begin{abstract}
This article is an attempt to understand the impact of changes have occurred, and still ongoing in Libya after the Arab Spring protests that resulted in the fall of the authoritarian regime and the implementation of democratic governance mechanisms, considering both internal and external issues and the growing interdependence of different political-economic factors on the Libyan society in its transformation. After a series of disastrous actions of the Khadafi government, locally and internationally, the protests have led the company to a direct intervention war on the government and the State. The impact of American interventions in this change is prominent, due to the peculiar characteristics related to this position power on one side, and his strained relationship with Libya on the other. This paper presents some aspects of the problem arising from the ideological contradiction between Secularism and Political Islam with regard to participation in the new state and the principles of governance. This subject acquired a marked importance in the current intellectual and political debates in the Arab World. Now, more than ever, the democratic solution is the assumption conciliatory between two opposing currents, whose confrontation took off from the stage of theoretical discourse to the level of armed struggle.
\end{abstract}

Keywords: Libya. Secularism. Political Islam. Arab World. Democracy. 


\section{Introdução}

A mobilização popular, a atuação de grupos armados e a intervenção da comunidade internacional representam a rodada final que derrubou o regime ditatorial do coronel Muammar Khadafi na Líbia em 2011. Algumas questões relevantes, dentro do espectro de conflito e transformação, precederam estas ações, como sanções econômicas, condicionalidades políticas, isolamento e pressões de toda espécie que por décadas foram impostas ao Estado líbio. Neste contexto, a transição para a democracia resulta de razões ligadas principalmente ao conjunto de três fatores fundamentais: o desejo às liberdades e aos valores democráticos; a insatisfação atribuída à crise econômica no ambiente interno; e a natureza atroz das ações terroristas do governo no meio externo. A síntese da interação destes três fatores interdependentes foi marcante na condução à erosão da legitimidade do antigo sistema, sua instabilidade e, finalmente, sua desintegração. Podemos entender o fenômeno de crise e transformação do sistema político líbio em dois estágios: o primeiro representa um lastro de ações produzidas pelo antigo regime líbio de sentido dual (o despotismo interno e o terrorismo externo), resultando em um sintético fato caracterizado pela violência direcionada à sociedade líbia de um lado e à comunidade internacional de outro; e o segundo é entendido em termos de reações, por parte dos afetados (a sociedade líbia e a comunidade internacional), a um processo carregado de pressões.

É necessário considerarmos aqui a preponderante atuação da comunidade internacional no processo de derrubada do governo e transformação do poder no Estado líbio. Atores externos foram relevantes no cenário de mudança de regime, em especial destacase o papel dos Estados Unidos da América (EUA) e da Organização das Nações Unidas (ONU), através do seu Conselho de Segurança, como veremos mais adiante. Desde a transformação dos regimes comunistas, como relata Pridham (2008), ocorreu um enorme impacto sobre a reconfiguração do sistema internacional: a era pós-Guerra Fria instituiu características destacadas pela emergência de novas tecnologias e pelos efeitos mais amplos da globalização, que tornaram o mundo mais interligado e os efeitos internacionais bem mais transmissivos. Com isto, o foco da política exterior dos EUA logo se deslocou do confronto ideológico com a
ex-União Soviética para uma série de questões ligadas à promoção da democracia, à solução de conflitos decorrentes da transição democrática e ao enfrentamento do terrorismo e dos sistemas antidemocráticos. Esta mudança de rumo na política externa dos EUA levou esta potência a novas incursões no mundo periférico, fora do eixo norte-ocidental, inclusive na atuação direta na queda do antigo regime e na formação do novo Estado líbio.

Entretanto, com o novo Estado nasceram novos conflitos, que representam os aspectos mais dificultosos à estabilidade administrativa do país e à formação de sua democracia. Duas correntes disputam sobre o tipo do Estado a ser estabelecido: a Federalista e a Unitarista. O argumento dos federalistas está baseado na problemática da marginalização e exclusão das regiões periféricas como consequência da adoção de um sistema centralizado, defendendo assim a autonomia das regiões. No sentido oposto, os unitaristas, apoiados pelo atual governo, afirmam que a questão pode ser resolvida por meio de um sistema administrativo local, centralizador das políticas de governo. Porém, o maior e mais preocupante conflito gira em torno de dois vetores divergentes que têm dominado o debate político na Líbia: o Secularismo e o Islamismo Político. O primeiro fundamentado na democracia liberal e o segundo ligado à percepção islâmica.

Devido ao seu peso histórico na formação política do Mundo Árabe, o Islamismo Político não pode ser ignorado nos estudos sobre a reconstrução do Estado líbio. Escusado será dizer que a necessidade de inclusão do conhecimento sobre a corrente do Islamismo Político vem dos desafios que têm ameaçado o processo democrático na região. Na ausência de um modo democrático conciliador nas relações entre os Islamitas e os Secularistas, as chances de convivência harmoniosa entre estas duas correntes têm diminuído constantemente.

\section{Considerando a democracia periférica}

Como a democracia se caracteriza no seu início e como pode ser vista atualmente no caso da Líbia? Para analisarmos o Estado observado, precisamos inicialmente esclarecer o que marca, neste trabalho, um regime democrático e o que o diferencia do autoritarismo. $\mathrm{Na}$ classificação de um regime como democrático, o primeiro critério aqui observado é se os cargos de governo e de parlamento são submetidos à escolha do 
povo, através de processo competitivo, livre e limpo, ou seja com a existência de mais de um partido político e a alternância de poder (PRZEWORSKI et al, 2000). O segundo critério é a existência do sufrágio universal, o que garante o direito de participação à larga parcela da população nacional (DAHL, 1971). O terceiro critério por nós observado é se os direitos políticos e as liberdades civis são respeitadas, incluindo a liberdade de imprensa, de expressão, de organização e de oposição, sendo estes direitos protegidos por garantias constitucionais (MAINWARING et al, 2001). O quarto critério é a certeza de que as autoridades eleitas possuem condições reais para o exercício de governo, sem a ingerência de forças militares (MAINWARING et al, 2001).

Dewey (1984), por sua vez, assinala que democracia como ideia social e democracia como sistema de governo estão conectadas. Ambas permaneceriam estéreis e vazias se não tivessem encarnado nas relações humanas, ou seja, a ideia de democracia é muito mais ampla e complexa para ser exemplificada apenas no âmbito do Estado, e para ser realizada deve envolver todos os modos de associação humana, inclusive a família, a escola, o trabalho e a religião, além das instituições políticas, que são mecanismos indispensáveis que garantem canais de operação ativa. Assim, adotamos como quinto critério o interesse e a participação popular na vida política de sua sociedade, compreendendo que a função da democracia não reside apenas na sua fase política relacionada à seleção do governo, tampouco na determinação das suas políticas, apesar de que esta segunda função ainda não está sendo realizada de uma maneira satisfatória, isto é, com a democracia participativa desempenhando papeis mais importantes, ligados à unificação do público disperso a fim de expressar e definir os seus interesses. Neste mesmo sentido, Callon (2013) insiste que os cidadãos não devem ser mais meramente agentes passivos, mas sim transformados em autores de suas próprias ações e iniciativas. A interatividade incita o cidadão a interagir cada vez mais com as questões deliberadas. $\mathrm{O}$ cidadão não mais absorve discursos e ideologias apenas, mas tem se envolvido em um agenciamento interativo, como beneficiário e como afetado pela política que participa e intervém na governança.

Portanto, é considerado democrático nesta análise o Estado que realiza eleições abertas e limpas para o Legislativo e o Executivo, permite a universalização do direito de voto, garante as liberdades civis e os direitos políticos aos seus cidadãos e é, de fato, governado pelo político eleito para isto, além de contar com a participação popular na política. Esta descrição básica de democracia, adotada para este trabalho, não nega a existência de outros critérios inerentes ao Estado democrático moderno, entretanto consideramos estes cinco critérios como essenciais e de possível identificação no caso analisado.

Os critérios aqui adotados para indicar um Estado de regime democrático somam um conjunto de valores que não surtem efeitos se adotados isoladamente. A falta de um destes critérios não pode ser compensada, nem mesmo com a ampliação de outro, levando em consideração a argumentação de O'Donnell (2001) de que diversos regimes satisfazem o princípio das eleições competitivas, mas não cumprem outros princípios essenciais, ficando assim aquém de uma democracia.

\section{Secularismo e Islamismo Político}

A introdução das ideias seculares no mundo árabe começou com a invasão napoleônica ao Egito, em 1798, acompanhada por um conjunto de princípios, formas de organização e modos de administração. Quando Muhammad Ali, encarregado pelo Império Otomano de combater o Exército Francês, conseguiu expulsar os invasores, foi recompensado com o cargo de governante do principado do Egito, em 1805, e resolveu manter as novidades trazidas pelos franceses. Muhammad Ali desejava constituir um império árabe com bases científicas e estabeleceu uma classe média iluminadora, capaz de lançar normas e leis modernas para um Estado inovador. Muitos incentivos foram concedidos aos egípcios para estudarem na Europa e esses estudos tiveram um grande impacto na transmissão dos princípios do conhecimento secular e da democracia liberal no Egito e, por conseguinte, no Mundo Árabe. De acordo com Zahir (1994), naquela época não existiam atitudes antagônicas ao secularismo e à democracia, ao contrário, havia uma espécie de admiração pelos modos modernos de organização social e pelos novos estilos da vida. Entretanto, no auge da luta contra o colonialismo, durante o Século XX, a corrente islâmica liderou o movimento de libertação, mas logo depois da independência foram os grupos seculares que ascenderam ao poder, enquanto os grupos islâmicos foram afastados e perseguidos pelas elites dominantes apoiadas pelo Ocidente.

O radicalismo secular, como afirma Asshaikh 
(1997), foi o próprio responsável pelo surgimento de atitudes anti-seculares representadas pelas ações do Islamismo Político. Depois da Segunda Guerra Mundial, os países árabes, sucessivamente, conseguiram adquirir a independência e os secularistas, notadamente da Corrente Nacionalista Árabe, de inclinação esquerdista e representada de uma forma quase que geral por militares, delimitaram o espaço das liberdades e dos direitos ao monopolizar os recursos do conhecimento, do poder, da lei e da legitimidade. Com isto, os governantes árabes secularistas daquela época desvincularam-se da realidade dos seus povos. Miller e Martini (2013) relatam que os modelos de governança, como os executados pelos secularistas, enfraqueceram-se por ações impostas contra a vontade popular e foram constantemente erodidos por decisões inadequadas e projetos inviáveis. O prazo entre a época da independência, em meados do Século XX, e o final da primeira década do Século XXI, preparou o solo para uma reação violenta por parte de grupos religiosos. Logo depois da queda dos regimes seculares pelos levantes da Primavera Árabe, a situação pareceu favorável para que o modelo do Islamismo Político fosse aplicado. E assim começou outra rodada de conflitos entre as duas correntes. No passado, os métodos seculares árabes foram acompanhados por projetos ditatoriais. No presente, a democracia mudou, inicialmente, a situação a favor do Islamismo Político, que semelhantemente repetiu a mesma experiência ditatorial com a tentativa de islamização do Estado, o que fortaleceu os seculares na luta pela retomada do poder.

$\mathrm{O}$ advento da democracia seria um recomeço necessário para constituir um Estado como instituição laica, neutra a ambos os grupos. A condição necessária para realizar este objetivo é a libertação da política das armadilhas teológicas. Mas no caso das sociedades árabes isto parece impossível, pelo menos no formato de um secularismo universal. Por este motivo, como explica Almesisri (2002), apenas pode ser aplicado um secularismo relativo.

Nos regimes derrubados pela Primavera Árabe, geralmente marcados por princípios déspotas personalizados, os ditadores condensavam os recursos do poder, do conhecimento, da lei e da legitimidade em suas mãos. Com isto, tanto as facções da corrente secular, quanto as do Islamismo Político, como também as categorias populares, foram fortemente impedidas da participação ativa. Esta exclusão, acompanhada de uma forte repressão, foi uma prática responsável pela dissolução desses regimes. Observa-se que as práticas de exclusão e do confronto recíproco continuam ameaçando a legitimidade do regime democrático recém-nascido e a contradição entre as duas correntes ainda parece inconciliável. É que estamos diante de um grupo que fala em nome da Terra e outro que se faz porta-voz do Céu. De uma forma geral, o Islamismo Político, como todos os grupos pertencentes à corrente islâmica, converge aos princípios comuns do pensamento político: a soberania da governança de Deus, a igualdade, a deliberação, a garantia de direitos e liberdades, a obediência ao governante e a responsabilidade deste. O Islamismo Político defende estes princípios gerais como forma de união de todos os grupos islâmicos, a Umma. ${ }^{3}$ Isto corresponde ao que Ibraheem (2011) apresenta como o conteúdo da política constitucional de Sharia, um conjunto de relações que une governantes e governados dentro de uma mesma rede de direitos e obrigações recíprocas.

A governança em nome de Sharia representa uma alternativa competitiva ao modelo secular. Almaraquibi (1994) afirma que qualquer que seja a sua posição ao longo do espectro da distribuição dos grupos islâmicos, entre o mais radical e o mais moderado, considera que a Constituição e as leis, os modos de vida e do comportamento social devem seguir a Sharia (a Lei Divina derivada da interpretação do Alcorão), o Sunnah (discursos e atos explicadores das normas do Profeta Maomé) e as tradições dos Califas (sucessores do Profeta). Estes princípios sagrados constituem uma fonte única de reconhecimento e de apoio aos grupos políticos islâmicos, que podem ser divididos em duas correntes: a dos moderados e a dos radicais. A primeira adota o método mais democrático, enquanto a segunda o rejeita completamente. O grupo da Irmandade Muçulmana, por exemplo, representa a primeira categoria, enquanto os grupos Ansar al-Sharia, Jihad e Al-Qaeda representam a segunda. Zahir (1994) lembra que quando o Estado do Paquistão tornou-se independente, em 1947, Muhammad Assad foi encarregado como Presidente do Comitê de Promulgação da Constituição do Estado Islâmico Paquistanês. Ele passou três anos procurando

3 Termo que se refere à comunidade formada por todos os muçulmanos do mundo, independente de etnia, língua, gênero e posição social, unida pela crença no profeta Maomé e guiada pelas orientações do Alcorão. 
no Alcorão e nas normas do Profeta Maomé sobre projeto de Estado ou constituição, mas seus esforços foram em vão. $\mathrm{O}$ autor afirma que o conflito entre estas duas correntes tem se intensificado em torno da questão da governança e a problemática principal tem sido relacionada a má compreensão do Islã e do Secularismo por ambas as partes. $\mathrm{E}$ ao que nos parece, o antagonismo que caracteriza as relações entre as correntes resulta de uma má compreensão da democracia.

Os seculares apresentam uma visão do Estado e da sociedade que não confunde o texto sagrado e o texto humano. Esta visão pressupõe que a mente humana é capaz de mobilizar os mecanismos do Estado e da sociedade. Ao contrário destes, a corrente islâmica entende que Deus formulou todos os detalhes da vida e por isso é necessário que o texto sagrado seja evocado na política, no Estado, na governança e na sociedade. Severamente, o conflito entre as duas correntes foi removido do círculo da teorização e do discurso para o campo da violência e do combate. Os grupos islâmicos, notadamente os mais radicais, não aceitam a democracia como sistema de governo. Para estes, os princípios democráticos contradizem o Islã por conceder competências de legislação ao povo e aos seus representantes, em vez de Deus.

$\mathrm{Na}$ observação de Alfadl (2003), os partidos moderados do Islamismo Político, representantes da corrente islâmica nos Congressos Nacionais, já possuíam poderes influentes nestas instituições e devido a sua eficácia organizativa e à posição proeminente no Legislativo, os membros destes partidos assumiram cargos ministeriais importantes, ocupam espaço no alto escalão do Executivo e participam da maioria das instituições públicas influentes. Contudo, só agora ocuparam o posto de comando do governo. Por isso, Al-Alimi (2014) observa que a corrente islâmica tem receios da exclusão herdada de sua experiência histórica de repressão pelo Estado. Pela primeira vez este grupo experimenta o exercício do poder, como resultado da Primavera Árabe, alcançando uma vasta margem de liberdade de ação. A frustração desta corrente ocorreu em 2013, no Egito, quando o presidente eleito, Mohamed Mursi, foi deposto um ano após assumir o cargo. $\mathrm{O}$ que ocorreu com o Partido da Irmandade Muçulmana no Egito afetou a corrente islâmica em outros países na região. E o receio desta corrente pelo retorno da exclusão tem provocado uma intensificação das ações violentas.

\section{Uma sociedade em transformação}

O estabelecimento de um processo de democratização na Líbia pressupõe a devida adequação em três instâncias constitutivas deste país: o governo, as instituições e o povo. A primeira instância, em nível de governo central, obteve uma mudança drástica com a derrubada do poder ditatorial de Khadafi e o estabelecimento de um novo governo, em contato mais próximo com a população do país. No que diz respeito às instituições, estas não obtiveram mudanças tão instantâneas quanto o governo, mas têm procurado se ajustar aos princípios democráticos com o estabelecimento de novas regras e práticas de trabalho que consideram as necessidades e demandas populares e buscam contemplar em suas ações as novas vontades do povo expressas nas manifestações livres ocorridas no que se intitulou de Primavera Árabe.

Ainda no que se refere às instituições, os meios de comunicação, por exemplo, antes efetivamente controlados pela mão forte do Estado, com a queda do regime passam por um sutil processo de transformação, tendo a imprensa local adquirido liberdades que desconheciam, livrando-se da censura controladora estatal. Nas escolas e universidade, semelhantemente, foram iniciadas mudanças gradativas após o fim do constante controle exercido pelo governo sobre os conteúdos, os métodos e a própria docência. Também o empresariado nacional, que mantinha um descontentamento latente com as duras políticas estatais, enxergou no fim do regime ditatorial a vantagem de aquisição de novos investimentos, principalmente externos, além da ampliação da livre concorrência, isto porque apenas um pequeno grupo de empresários, mais ligado ao governo central, se beneficiava pela posse de privilégios de mercado.

Sobre esta situação de descontentamento coletivo, Almgareef (2008) lembra que quando o golpe de Khadafi derrubou a monarquia e assumiu o poder, em 1969, não tinha consigo um plano de ação política, por isso suas ações foram contínuas práticas de conflitos internos e externos. E isto tornou o caos como característica relacionada ao seu domínio: a Constituição foi abolida e as leis anuladas; os papeis das organizações e sindicatos trabalhistas e estudantis foram substituídos por outros condizentes ao regime; restrições severas sobre as liberdades de expressão, pensamento e cultura foram 
criadas; todos os tipos de partidos e organizações políticas foram proibidos e violentamente silenciados; a organização militar foi drasticamente desestruturada por conta da perseguição aos oficiais oposicionistas, que foram assassinados ou exilados.

Diferentemente do Egito, que dispõe de um exército forte, a Líbia de Khadafi desmontou sua estrutura militar temendo um golpe dentro do golpe. Não era intenção do governo, que chegara ao poder através da força, fortalecer um exército que poderia repetir a façanha tentando tirá-lo do poder. Por isso Khadafi fortaleceu sua guarda armada, mas não investiu o necessário na força nacional. Este é um ponto que diferencia bastante as ações de protestos da Primavera Árabe nestes dois países. Enquanto no Egito a população encontrava-se desarmada, lutando com paus e pedras e sem ameaçar os militares, na Líbia os grupos rebeldes receberam armamentos de fornecedores estadunidenses e entraram em confronto armado direto contra um exército fragilizado. As manifestações egípcias uniram o novo e o velho em técnicas de conflito: a tecnologia da internet usada para mobilizar a população e as pedras lançadas como armas de uma guerra primitiva. $\mathrm{Na}$ Líbia, pelo contrário, os combates produziram efeitos mais violentos, confrontando grupos civis que receberam armas do exterior e mercenários contratados pelo governo para impedir o avanço dos rebeldes.

Nos 42 anos de governo de Khadafi, as decisões governamentais anularam a legitimidade e a legalidade do Estado então existente e visões despóticas passaram, então, a perturbar a vida civil, instituindo arbitrariamente mecanismos aleatórios e irracionais de governança. O regime tornou a violência, a opressão e o terrorismo um modo de lidar com todos os setores da sociedade. Por isto não é difícil entender o grande ressentimento que havia nas instituições e, por conseguinte, a adesão coletiva ao movimento que apontava para uma real possibilidade de derrubada do ditador. O medo da reação do governo e a conhecida penalização dos culpados fez com que muitos dirigentes de instituições e autoridades públicas não aderissem inicialmente ao movimento, ou dele participassem timidamente. Posteriormente, quando as manifestações ganharam as ruas como uma ação sem volta, visto pelas demonstrações de fraqueza do governo, a ponto de querer negociar com os oposicionistas e ofertar vantagens para desmobilizá- los, as instituições passaram a apoiar efetivamente o movimento.

Tanto o novo governo quanto as instituições líbias apresentam agora uma alteração de rota rumo à formação de um novo Estado. Mas e o povo líbio? O que o levou a iniciar este processo? É possível descrever o povo líbio como um conjunto de tribos diversas com baixa experiência democrática. Esta geração ativamente participante dos movimentos de derrubada do regime não havia conhecido a democracia em seu país. O longo período de governo autoritário de Khadafi fez com que a população não tivesse contatos ou referências democráticas em seu próprio meio. Porém, as relações destes mais jovens com grupos externos sempre foi algo presente. Isto porque, como bem sabemos, as fronteiras africanas são artificiais, estabelecidas pelos colonizadores europeus no Século XIX, e com isto tribos foram separadas em países diferentes e o tempo não extinguiu os laços familiares e tribais, fazendo com que as relações afetivas cruzassem as limitações geográficas e os impedimentos estatais de domínio e controle do espaço territorial. Assim, cidadãos líbios mantinham contatos permanentes com parentes e amigos na Argélia, Tunísia e Egito. De outro lado, apesar de manter-se fechado durante o regime autoritário, o Estado líbio permitiu a muitos jovens frequentar escolas e universidades europeias. A proximidade entre os países da África Meridional e a Europa favoreceu o intercâmbio de estudantes que conheceram a democracia em diferentes sociedades europeias, visões de mundo que voltaram ao país de origem através dos mais jovens e acadêmicos. A proximidade dos continentes também favoreceu as migrações, existindo diversas famílias líbias com parentes vivendo em países europeus, com os quais cultivavam contatos.

O sonho das liberdades trazidas pela democracia incitou-os à ostentação das indignações e descontentamentos e aos protestos em massa, sobretudo após o sucesso do movimento no principal país vizinho, o Egito, onde o governo de Hosni Mubarak desmoronou após 30 anos no poder, não resistindo aos protestos populares que ganharam as ruas insistentemente.

\section{Interferências externas}

São inegáveis os incentivos e as influências dos EUA na expansão dos ideais democráticos em sociedades submetidas a governos e regimes autoritários. Esta 
promoção da democracia no exterior não é apenas produto de um impulso idealístico, mas reflete o envolvimento pragmático baseado na Teoria Realista ${ }^{4}$ que nos ensina que a política externa possui uma estratégia racional ligada à maximização do poder e à realização dos interesses nacionais. Esta teoria também apresenta um caráter pragmático quando pressupõe que a democratização traz consigo um ambiente favorável à realização dos interesses nacionais dos EUA.

Sabe-se que atores externos influenciam mais efetivamente sistemas com necessidades urgentes de assistência financeira, técnica ou política. Em troca dessa assistência, países centrais impõem prescrições políticas aos periféricos a fim de suscitar-lhes uma transformação econômica. E a motivação exterior em forma de políticas estratégicas representa um elemento determinante no impacto sobre a democratização do país. Ikenberry (1999) observa que a política externa dos EUA reflete esta compreensão pragmática e sofisticada de criar uma ordem mundial estável e relativamente pacífica, isto porque, segundo o autor, dentro do que pode ser chamado de A grande estratégia liberal, a preocupação americana com a promoção da democracia no exterior se encaixa numa visão maior sobre os recursos de uma ordem internacional legítima, segura e próspera. A política externa dos EUA, orientando-se pelo idealismo wilsoniano, ${ }^{5}$ emprega esforços para fins pragmáticos, isto é, a guerra pode ser evitada e isto favorece plenamente o mercado e o liberalismo econômico, pois os Estados democráticos dificilmente entram em conflito bélico com outros democráticos, então a expansão desse tipo de governo e a promoção de instituições democráticas diminui a possibilidade de guerra. A ampliação dos Estados governados democraticamente estimula a criação e sustenta a manutenção de organizações e leis internacionais, o que, por sua vez, facilita a difusão da

4 A teoria realista das relações internacionais tem um caráter pragmático, sendo o Estado apresentado como o ator central. O Estado atua sempre pelos interesses nacionais e o poder é o instrumento que garante a sua sobrevivência no cenário internacional (MORGENTHAU, 2003).

5 Na teoria das relações internacionais, o idealismo wilsoniano se refere à escola de pensamento que, na história diplomática dos EUA, tem identidade com os ideais kantianos e se contrapõe ao realismo político. Após a Primeira Guerra Mundial, o idealismo liberal de Woodrow Wilson procurou entender as causa da guerra e prescrever formas de evitar outro conflito com tamanhas proporções. democracia em âmbito internacional, favorecendo a globalização. Mesmo quando, em algumas ocasiões, os interesses dos Estados democráticos são antagônicos e conflituosos, estes buscam a resolução dos conflitos através de ações legais, estabelecidas pelo direito internacional e mediadas por organismos internacionais. A estratégia liberal americana parte da convicção de que as características dos sistemas políticos de outros países têm um grande impacto sobre a capacidade dos EUA em garantir a sua segurança e seus interesses econômicos.

Por isto, exportar democracia permite aos Estados industriais do norte-ocidental realizar seus interesses materiais enquanto potências econômicas. Mas reconhecemos que a capacidade desses Estados de influenciar o caráter democrático de outros é extremamente limitada. Também é possível enxergar a promoção democrática como uma forma de neocolonialismo, onde se dá a imposição de características culturais ocidentalizadas. As formas de intervenção, segundo Schraeder (2010), variam entre a provisão de assistência externa, a adoção de condicionalidades políticas, as sanções econômicas, a intervenção bélica direta e o apoio à insurgência e à guerrilha a fim de derrubar os regimes autoritários. Sobre este fato, levantase um questionamento interessante: será lícito que a democracia seja construída por meios não democráticos? Ao que parece, o uso da força se mostra ético se o fim é o ideal democrático. No caso líbio, especificamente, a intervenção da comunidade internacional parece ter sido legalizada pela Lei Internacional e a imposição da democracia legitimada pela massiva aceitação do povo líbio e pela aprovação regional e internacional.

A implantação da democracia nas periferias globais também se funda na recente guerra contra o terrorismo, e isto passou a funcionar como um tipo especial de projeto político dos EUA. As práticas institucionais contra o terrorismo são legitimadas e normalizadas pelo discurso produzido por um consenso afetado pela realidade. Era necessário produzir uma linguagem antiterrorista que não fosse uma reflexão neutra da realidade, mas foi cuidadosa e deliberadamente construída para legitimar o uso da força. Tal discurso retratou o terrorismo como catastrófico para democracia. No que se refere às relações entre democracia e segurança, Boudreau (2007) relata que estas estão implicadas, uma e outra, de modo complexo, sendo as estruturas que as influenciam identificadas nos níveis internacional, de um lado, e da sociedade doméstica, 
de outro, de modo que a aplicação de mais democracia tem sido invocada como um antídoto contra as ameaças à segurança que partem de lugares sem funcionamento de sistemas democráticos. Neste entendimento, em todas as estruturas, quer no nível internacional, quer no nível doméstico, democratas não vão à guerra contra democratas. Ainda cria-se uma cultura favorável à paz e à segurança, visto que os processos democráticos mudam as pessoas através de uma participação ativa que vai além do voto, uma participação onde as vozes do povo têm ressonância nas decisões do governo. Com o decorrer do tempo, novos modos pacíficos de comportamento emergem e se desenvolvem nessas sociedades.

\section{Conflitos e isolamento}

As primeiras evidências que encontramos da relação conflitante entre a Líbia e os EUA nos remetem à Guerra de Trípoli )1801-1805), quando o presidente americano Thomas Jefferson impôs um bloqueio naval e o navio de guerra Philadelphia, encarregado da missão, foi capturado pela força marítima de Trípoli, então uma Província otomana. Desde então houve uma trégua até o final da Segunda Guerra Mundial, com a derrota do Eixo, quando a Inglaterra ocupou o Norte da Líbia, então dominado pela Itália, e concedeu a base aérea militar
Republicano Irlandês) e até mesmo os EUA (com a Nação do Islã). O anti-imperialismo, o confronto com Israel, o suporte às revoluções contra os regimes conservadores, estes foram os principais pilares do regime de Khadafi.

Desde então, a violência esteve intrinsecamente relacionada ao antigo regime ditatorial líbio. O governo de Khadafi agia do mesmo modo, quer internamente pelo despotismo, quer no âmbito internacional pelo terrorismo. De acordo com Alburi (2007), Khadafi tinha ações caóticas no exercício do governo e essas ações consistiam no patrocínio e na prática do terrorismo, bem como na intervenção e no controle direto e centralizado dos assuntos internos do Estado. O terrorismo externo, que horrorizava o estrangeiro, era acompanhado por um despotismo similarmente violento que oprimia os cidadãos internamente, ou seja, as práticas externas eram também reflexos do que se passava internamente. A violência interna atingiu todas as instituições nacionais, inclusive a educação, onde os programas foram alvos de modificações arbitrárias, enquanto alunos e professores foram sumariamente executados ou afastados de suas atividades. Os direitos de propriedade foram violados pela desapropriação e confisco de bens. As práticas diárias de destruição sistemática das estruturas, das instituições e dos quadros legítimos foram a razão de uma onda de descontentamento popular. Estas práticas internas, violadoras da ordem social, se estenderam também ao relacionamento do regime no âmbito externo.

As ações violentas aumentaram na década de 1980, como afirma Arrgaei (2009), quando a oposição líbia refugiada nos países ocidentais foi perseguida. Os esquadrões da morte, instituídos secretamente pelo governo, executaram ativistas pertencentes à oposição em Bonn, Milão, Atenas, Roma e Londres. Os EUA acompanhavam o comportamento do regime e assim que o presidente Ronald Reagan assumiu o seu mandato rompeu relações diplomáticas com o governo líbio. Em agosto de 1981, jatos líbios foram derrubados pela Força Aérea dos EUA no Golfo de Sirte. Isto porque, desde 1974, o coronel Khadafi declarou que as águas abaixo de $32^{\circ} 30 \rrbracket$ eram território da Líbia, violando os tratados internacionais, o que levou os EUA a fazerem um protesto oficial, que foi ignorado pelo governo líbio. Em 1982, Reagan impôs um embargo comercial sobre a Líbia, inclusive sobre a exportação de petróleo. Como consequência desta decisão, o rendimento do Estado líbio caiu para um terço. Em 1986, o regime líbio foi acusado 
de envolvimento em atentados palestinos nos aeroportos de Roma e Viena, e em abril do mesmo ano uma bomba explodiu em um clube de Berlin, fatos que levaram os EUA a atacarem as residências de Khadafi nas cidades de Trípoli e Benghazi. A década de 1980 encerrou-se com o atentado contra o avião americano da Pan Am na cidade inglesa de Lockerbie, em 21 de dezembro de 1988, e outro contra um avião francês da UTA, em 10 de setembro de 1989. Mais que 400 pessoas morreram em ambos os atentados. Em novembro de 1991, os EUA acusaram a Líbia pelos dois atentados e daí começou uma década de isolamento internacional.

Foram os atentados contra os aviões da Pan Am e da UTA os episódios que levaram EUA, Inglaterra e França a recorrerem ao Conselho de Segurança da ONU com o pedido de sanções ao governo líbio. Isto aconteceu fora das regras tradicionais do litígio, numa ação sem precedentes, quando o Conselho de Segurança tomou, por unanimidade, uma série de Resoluções: No 731, de 21 de janeiro de 1992, que se refere ao envolvimento de oficiais do governo líbio em atos terroristas; No 748, de 31 de março de 1992, que ordenou a Líbia a responder imediatamente aos pedidos dos três países (EUA, Inglaterra e França); No 883, de 11 de novembro de 1992, que estendeu o escopo de sanções para incluir um congelamento parcial de fundos no exterior e uma precaução no fornecimento de equipamentos industriais petrolíferos. O Conselho ainda impôs sanções que incluíram a proibição de voos, a suspensão do comércio de armas e a redução no tamanho das missões diplomáticas líbias no exterior.

Estas sanções promoveram, de acordo com Merza (2012), uma necessária abertura interna que incluiu tanto a economia como a política da Líbia. No aspecto econômico, desmoronou o modo de economia planificada, sendo a iniciativa privada instituída e paralelamente edificada uma adaptação estrutural econômica compatível às políticas sugeridas pelas instituições internacionais, como o Banco Mundial e o Fundo Monetário Internacional. No sentido político, ocorreram mudanças em termos de garantias de liberdades, de rejeição dos tribunais revolucionários, da proibição das penas que violam a dignidade humana e da liberação da maioria dos presos políticos. A Lei № 20, de 1992, de Suporte de Liberdades, incluiu garantias de direitos de circulação e residência, a independência do Judiciário e o acesso ao justo julgamento. Como efeito desta abertura política e econômica, as organizações da sociedade civil começaram a surgir, ao mesmo tempo em que camadas consideráveis da população sentiram-se mais independentes economicamente, e assim estas novas condições de abertura fizeram aumentar as reivindicações populares por mais liberdades e mais democracia.

Só em 27 de agosto de 1998 o Conselho de Segurança tomou a Resolução No 1192, que suspendeu as sanções ao Estado líbio depois do cumprimento das obrigações determinadas e da entrega às autoridades internacionais dos indivíduos acusados pelo atentado terrorista contra a Pan Am, depois de uma longa mediação feita por Nelson Mandela e membros da Família Real Saudita. Por fim, a Resolução No 1506, de 12 de setembro de 2003, derrubou plenamente todas as sanções anteriores depois de uma aproximação diplomática entre os EUA e a Líbia, quando estes dois países acordaram, após extensas rodadas de negociações, sobre a forma de indenização às famílias das vítimas do atentado aéreo. Entretanto, vários grupos oposicionistas ao governo, residentes no exterior, continuaram sendo patrocinados por organizações dos EUA, a exemplo do general Khalifa Haftar, como veremos mais adiante. Depois da queda de Khadafi, estes voltaram ao país contando ainda com o apoio dos EUA para o fortalecimento das instituições democráticas recémcriadas e o combate ao terrorismo de Estado, seguindo um plano político e desenvolvimentista. Paralelamente, diversas agências estadunidenses se inseriram no governo líbio com vários programas de promoção à democracia e esforços tecnocráticos de assistência na mudança política de gestão, muitas vezes se estendendo da governança ao fortalecimento da sociedade civil. A maior instituição neste sentido é a Agência dos Estados Unidos para o Desenvolvimento Internacional United States Agency for International Development (USAID) -, além de outras principais que são a Doação Nacional para Democracia e o Departamento de Estado. Outras instituições participantes na promoção da democracia na Líbia são o Instituto Democrático Nacional e o Instituto Republicano Internacional, ambos mantidos pelos dois grandes partidos políticos estadunidenses.

\section{Política na Líbia hoje}

Mesmo depois da queda do regime de Khadafi e a instituição de um governo provisório logo após o encerramento dos protestos da Primavera Árabe, a situação política na Líbia permanece delicada, com a classe dirigente enfrentando inúmeros desafios herdados 
do regime passado, que por 42 anos deixou tudo a ser reconstruído. Apesar de alguns avanços recentes, existem preocupações emergenciais no que se refere à segurança da população e à manutenção da ordem. O governo nacional não tem conseguido impor a sua autoridade às milícias que se formaram e se legitimaram na revolta contra a ditadura. As forças locais que não se sentem contempladas nas ações do Estado nacional continuam lutando com a mesma intensidade que lutaram na eliminação do poder ditatorial de Khadafi.

Na cidade de Benghazi, na luta por mais autonomia para a região de Cyrenaica, no litoral leste do país, a milícia liderada por Ibrahim al-Jathran chegou a bloquear terminais de exportação de petróleo e sitiar a cidade com o fechamento do aeroporto e de alguns prédios públicos. Os frequentes protestos em Benghazi exigem a realização de novas eleições parlamentares e também a realização imediata de eleições presidenciais, além da suspensão do Congresso Geral Nacional (CGN), que desde a morte de Khadafi tornou-se a principal autoridade política líbia, formado por deputados eleitos no início de 2012 para um mandato emergencial até a normalização do país, a regularização dos serviços públicos e a realização de novas eleições.

O primeiro governo de transição, liderado por um primeiro-ministro eleito no CGN, apresentou dificuldades em impor a ordem em regiões controladas por milicianos e em março de 2014 os membros do CGN o depuseram e logo nomearam o seu sucessor, o primeiro-ministro interino, Abdullah al-Thinni, com a responsabilidade de formar um novo governo na tentativa de estabilizar as relações políticas nacionais. Poucos dias depois, este renunciou afirmando ter sofrido graves ameaças de grupos oposicionistas.

Outro problema enfrentado no país diz respeito à baixa participação política no processo eleitoral para o legislativo e à crise política oriunda da disputa entre nacionalistas liberais e islamitas pelo exercício do poder executivo, fato que permeia de instabilidade o Estado nacional. Nas eleições parlamentares, menos da metade dos eleitores aptos a votar participaram dos pleitos. E na última eleição, realizada em junho 2014, o comparecimento foi ainda inferior ao registrado no ano de 2012, quando ocorreu a primeira eleição. Na comparação entre os dois pleitos há uma considerável redução no quantitativo de votantes: na primeira eleição, em 2012, havia 2,8 milhões de eleitores registrados. Já na eleição de 2014, apenas 1,5 milhão de elei- tores estavam registrados e aptos a votar. Isto ocorreu, de certa forma, porque houve um endurecimento das regras eleitorais. De outro lado, há uma descrença na política e o consequente afastamento do eleitor que não se vê contemplado nas ações governamentais. Além disso, em algumas regiões do país ocorreram conflitos armados e boicotes que impediram ou dificultaram a participação na votação. Neste mesmo ano, eleitores foram às urnas para eleger conselheiros municipais em 56 cidades. Também novos deputados foram eleitos para elaborar a nova constituição do país. Inicialmente, este grupo constituinte seria formado por 60 membros (o Comitê de Sessenta), mas apenas 47 começaram os trabalhos devido à violência em Derna, centro islâmico no leste, o que inviabilizou as eleições nesta região, além do boicote promovido pelos Amazigh (ou Berberes) em algumas partes do país. No início dos trabalhos, milicianos armados invadiram o Parlamento e suspenderam a legislatura encarregada de redigir a nova constituição nacional. Para agravar ainda mais a instabilidade no país, o embaixador da Jordânia foi sequestrado em Trípoli por milicianos opositores ao governo.

Em outo momento, novamente homens armados invadem o Parlamento e abrem fogo contra os deputados, impedindo a eleição do novo chefe de governo. Posteriormente, numa eleição tumultuada, o empresário Ahmed Maiteeq é eleito premiê e tem o seu nome confirmado pelo presidente do Parlamento. Entretanto, grupos rebeldes que não aceitaram o primeiro-ministro invadiram e controlaram alguns portos petrolíferos, o que representa não apenas a instabilidade política do governo, mas também a crise econômica do Estado com o desmantelamento do setor mais produtivo de sua economia.

Nos permanentes confrontos pelo acesso ao poder e em discordância à eleição de Maiteeq, membros da milícia comandada pelo general Khalifa Haftar entraram em choque com militantes islâmicos da milícia do Ansar al-Sharia. Fato que levou o presidente do Parlamento a pedir para que as milícias islamitas se mobilizassem para impor o controle em Trípoli, depois que as forças de Haftar invadiram a sede do legislativo. Em seguida, os legisladores, reunidos na cidade de Tobruk, no extremo leste do Líbia, longe dos conflitos entre militantes das milícias rivais, pediram da ONU o empenho na constituição de uma força internacional de intervenção para impedir o crescimento da violência miliciana que dividiu o país.

Haftar, que havia sido general de Khadafi, mas 
rebelou-se contra este em 1980 e se refugiou nos EUA, declarou-se um nacionalista e opositor do Islamismo Político, a quem acusou de ligação com o grupo terrorista Al-Qaeda. Haftar também acusou a Irmandade Muçulmana de apoiar, através de forças do Catar e da Turquia, grupos terroristas islâmicos. Isto levou os manifestantes de volta às ruas, desta vez em apoio ao general Haftar, que também conseguiu agregar o apoio das forças especiais do exército líbio. Por fim, a Suprema Corte do país, sob pressão dos protestos nas ruas, dos nacionalistas, das forças armadas e do poder do general Haftar, anulou a eleição de Ahmed Maiteeq, realizada em sessão parlamentar tumultuada, declarando que o processo havia sido ilegal.

\section{Considerações finais}

Desde o fim da Guerra Fria, criou-se nas sociedades democráticas a expectativa de que os regimes autoritários dos países do Oriente Médio e da África Mediterrânea sofreriam um processo de transformação política, semelhante ao ocorrido na América Latina e no Leste Europeu. Contudo, o que se viu foi o enrijecimento das ditaduras árabes. Entretanto, estes países enfrentaram uma crise econômica no âmbito doméstico e a consequente instabilidade política produzida pela crescente onda de insatisfação da população e pelo levante e fortalecimento da oposição. Na Líbia, por exemplo, não havia forças opositoras estabelecidas e organizadas, mas o processo de desmonte do governo autoritário fez surgir emergencialmente novas forças sociais autônomas, descontentes com a conjuntura social, política e econômica do país.

A Líbia, assim como os demais países envolvidos na Primavera Árabe, registrou uma característica comum, além do fácil acesso à nova comunicação através das redes sociais, foi a luta crescente por direitos políticos, sociais e civis. Isto favoreceu a formação de uma nova imagem da sociedade e incentivou os movimentos populares, e não podemos deixar de citar o importante papel do Catar através da emissora de televisão Aljazeera na transmissão das manifestações de rua, desde o seu início na Tunísia. A observação do ocorrido na região, envolvendo populações da vizinhança, incentivou a manifestação popular e de grupos de representação na luta contra o regime autoritário de Khadafi.

Durante as manifestações da Primavera Árabe na Líbia, grupos rebeldes contaram com o apoio do exterior, especialmente dos EUA, no enfrentamento ao governo de Khadafi. Este apoio, acompanhado de certa pressão, fez com que tais grupos fossem mais moderados em suas ações para serem aceitos por parte do povo e pela comunidade democrática internacional. Após a derrubada do governo, o caminho para a participação política foi aberto e isso, junto com as pressões externas, fez com que esses grupos revisem seus planos de atuação, optando pelo engajamento legal e legítimo no sistema e pela participação pacífica. Porém, com as ações iniciais do governo provisório, grupos que haviam lutado pela queda do governo ditatorial voltaram ao confronto por discordância dessas ações e por não encontrarem espaço no novo governo. Os confrontos se enraizaram em questões ideológicas, latentes no antigo regime, que colocaram em lados opostos Secularistas e Islamitas, defendendo respectivamente o Estado secular (laico) e o Estado religioso (Sharia).

Quanto à classificação do país como uma democracia, no que diz respeito aos cinco critérios inicialmente elencados, entendemos que a Líbia caminha progressivamente rumo a este destino, mas em conjunto, o processo ainda nos parece incipiente para ser caracterizado como democrático, apesar de seguir uma política de ajustes a estes critérios. O primeiro considera se o governo e o parlamento são formados por políticos escolhidos pelo povo. É inegável que na mudança de regime um esforço extraordinário foi e está sendo realizado rumo à democracia, começando com as Eleições Legislativas realizadas em 2012, as Eleições Municipais e a Eleição do Comitê de Sessenta, em 2014, para elaboração do projeto da nova Constituição, sinalizado que a Líbia está no caminho da construção democrática, apesar das dificuldades presentes. Estes processos eleitorais foram considerados competitivos, livres e transparentes por observadores internacionais que acompanharam cada um destes eventos.

Em relação ao segundo critério, do sufrágio universal, identificamos que o direito à participação nas eleições não impõe ao eleitor restrições ao acesso por gênero, localidade ou renda, apesar de que na comparação entre as eleições parlamentares de 2012 e 2014 registra-se uma diminuição no número de votantes, mas isto se deve ao endurecimento das regras eleitorais e não à exclusão de alguns estratos sociais. Sobre o terceiro critério, que trata do respeito aos direitos civis, compreendemos que este é parcialmente atendido, pois ainda não há 
garantias constitucionais das liberdades, visto que a nova constituição do país ainda está em construção, e também consideramos aqui os limites impostos em algumas regiões por circunstâncias religiosas, de um lado, e de grupos milicianos, de outro. Já o quarto critério, que aceita como democrático o regime no qual as autoridades eleitas governam, de fato e de direito, sem a ingerência de forças que tirem a autonomia do governante, identificamos uma grande dificuldade na construção de um campo de diálogo político entre o Islamismo Político e os Secularistas, sem que estas correntes busquem espaço no poder pela força das armas, isto porque dentre os grupos armados que derrubaram o governo de Khadafi há as milícias que precisam ser desarmadas e os conflitos violentos entre opositores que precisam definitivamente ser substituídos pela ralação dialógica. O exercício democrático eleitoral e as oportunidades de participação cívica já diluíram sistematicamente os confrontos em algumas partes do país, apesar de que, em algumas regiões e cidades importantes, a exemplo de Benghazi e Trípoli, grupos armados continuarem rivalizando belicamente e não debatendo democraticamente. Algumas instituições já estão se fortalecendo com o apoio governamental e as assistências externas. Agora, a dissolução das milícias, através de um programa de integração, representa uma prioridade tanto para o governo quanto para o povo líbio.

O quinto critério estabelecido aqui faz referência ao interesse popular e sua efetiva participação na política de sua sociedade. Neste caso percebemos o reduzido envolvimento no processo eleitoral provocado pelo descontentamento com o governo, além da conturbada disputa entre Secularistas e Islamitas e dos conflitos armados e boicotes em algumas regiões do país. Por estas razões, enxergamos um processo ainda em fase embrionária, de certa forma com base incipiente a qualquer constatação de consolidação democrática a curto prazo, de onde concluímos que, dada a instabilidade no Parlamento, com a dificuldade operacional dos congressistas, e a fragilidade do governo, inclusive com as sucessivas alterações do primeiro-ministro, não é possível nestes anos iniciais, subsequentes à derrubada do regime autoritário, proclamar o Estado líbio como democrático, face ao simultâneo estado de transformação e conservação em que se encontra a sociedade e às incertezas no estabelecimento do diálogo em superação aos conflitos entre grupos rivais. decretado pela ONU, a crise econômica interna, a guerra do governo dos EUA contra o terrorismo institucionalizado por Khadafi e as manifestações revolucionárias nos países vizinhos deslocaram a pressão da população e das instituições líbias para a cobrança por uma abertura democrática. As mudanças tiveram grande alcance tanto no âmbito governamental, quanto no da sociedade civil, além do campo econômico e dos direitos. Assim, o ritmo da abertura foi acelerado de tal forma que o regime autoritário já não conseguia mais controlar o nível das demandas por mais reformas. Com isto, as organizações da sociedade civil se proliferaram e estabeleceram relações com outras de sociedades democráticas, a mídia se tornou mais ousada e independente, a indústria começou a se modernizar com investimentos estrangeiros e o ensino está se reestruturando e se adaptando às novas tecnologias. A derrubada do antigo regime líbio, suscitada por um conjunto de fatores internos e externos, incluindo o isolamento, a crise econômica, a insatisfação popular e a intervenção bélica direta, na verdade foi um nocaute sobre um corpo que já era erodido.

\section{Referências}

AL-ALIMI, Ziad. A Irmandade Muçulmana: primeiros beneficiários, primeiros perdedores. Jornal Alarab, Londres, n. 9542, p. 6, 28 abr. 2014.

ALFADL, Munder. O Islamismo Político: o padrão e o modo de pensar. Beirute: Alhiwar Almutamadin, 2003.

ALMARAQUIBI, Jamal Assaied. O Califado Islâmico entre os regimes contemporâneos. Cairo: Faculdade de Direito da Universidade do Cairo, 1994.

ALMESISRI, Abdulwahhab. O Secularismo Relativo e o Secularismo Universal. Cairo: Dar Asshurouq, 2002.

ALMGAREEF, Muhammad Yousuf. A Líbia da Legitimidade Constitucional à Legitimidade Revolucionária: um estudo documentado analítico. Trípoli: Dar Wahba, 2008.

ARRGAEI, Saleem Nasr. Khadafi incitou a matar os adversários? Jornal Líbia Almustaqbal, 19 ago. 2009.

ASSHAIKH, Husain Abduzzahra. A problemática da relação entre a religião e as ciências no pensamento árabe contemporâneo: o secularismo como exemplo. Revista das Letras, Bagdá, v. 99, Faculdade de Letras da Universidade de Bagdá, 1997.

BOUDREAU, Vincent. Democratization and Security. Taylor Francis Online, Special Issue, v. 14, n. 2, 2007. 
CALLON, Michel. Europe wrestling with technology. London: Routledge, 2013.

DAHL, Robert. Polyarchy: participation and opposition. New Haven: Yale University Press, 1971.

DEWEY, John. The Later Works 1925-1953, v. 2, ed. Jo Ann Doydston, Carbondale and Edwardsville, Southern Illinois University Press, 1984.

IBRAHEEM, Muhammad Yusri. As participações políticas contemporâneas à luz da política de Sharia. Cairo: Dar Alyusr, 2011.

IKENBERRY, G. John. Why export democracy. WQ Spring, 1999.

MAINWARING, Scott; BRINKS, Daniel; PÉREZLIÑAN, Aníbal. Classificando regimes políticos na América Latina, 1945-1999. Dados, Rio de Janeiro, v. 44, n. 4, 2001.

MERZA, Ali Khudair. A Líbia: oportunidades perdidas e esperanças renováveis. Beirute: Instituição Árabe de Estudos e Publicações, 2012.

MILLER, Laurel; MARTINI, Geoffrey. The Democratic Transition in the Arab World: expectations and lessons. Disponível em: <http://www.rand.org/blog/2012/11/ in-brief-laurel-e-miller-and-jeffrey-martini-ondemocratization.html>. Acesso em: 20 fev. 2013.
MORGENTHAU, Hans. A política entre nações: a luta pelo poder e pela paz. Brasília: UnB, 2003.

O'DONNELL, Guillermo. Comparative politics and democratic theory. Studies in compatarive international development. v. 36, n. 1, 2001.

PRIDHAM, Geoferrey. International factors in democratization, their scope and limitation: European Comparative Perspectives on the post-Cold War World. In: TEIXEIRA, Nuno Severiano. The International Politics of Democratization: Comparative Perspectives. New York: Routledge, 2008. p. inicial-final.

PRZEWORSKI, Adam; ALVAREZ, Michael; CHEIBUB, José Antônio; LIMONGI, Fernando. Democracy and development: political institution and well-being in the World, 1950 - 1990. Cambridge: Cambridge University Press, 2000.

SCHRAEDER, J. Peter. The State of Art in International Democracy: results of a Joint European-North American. London: Research Network, 2010.

ZAHIR, Muhammad Kamil. O conflito entre a corrente secular e a religiosa no pensamento árabe moderno e contemporâneo. Beirute: Dar Albairouni, 1994. 